\title{
KONTINUITAS DAN DISKONTINUITAS PENDIDIKAN KADER PONDOK HAJJAH NURIYAH SHABRAN (1982-2014)
}

\section{- Azaki Khoirudin}

Universitas Muhammadiyah Surakarta (UMS), Indonesia Email: azakikhoirudin@gmail.com

\section{- Ma'arif Jamuin}

Universitas Muhammadiyah Surakarta (UMS), Indonesia

\begin{abstract}
Abstrak
Penelitian ini akan membahas masalah kontinuitas dan diskontinuitas paradigma pendidikan kader Pondok Pesantren Hajjah Nuriyah Shabran (1982-2014), dan kaitannya dengan diaspora peradaban Muhammadiyah. Tulisan ini mengamati transformasi dan pergeseran orientasi paradigma pendidikan kader Pondok Shabran pasca kepemimpinan Djazman al-Kindi, hubungan elit (kekuasaan) dalam pembentukan pandangan paradigma pendidikan, dan kontinuitas dan diskontinuitasnya. Landasan teori tulisan ini adalah teori diaspora, kontinuitas, serta diskontinuitas. Melalui Pondok Shabran, kader-kader Persyarikatan mampu melakukan diaspora peradaban dalam rangka membenihkan perubahan sosial.
\end{abstract}

Kata Kunci: Kontinuitas, Diskontinuitas, Pondok Shabran, dan Diaspora Peradaban Muhammadiyah 


\section{Pendahuluan}

Kiai Haji Ahmad Dahlan mendirikan Muhammadiyah (1912) sebagai hasil pemikirannya dalam memahami ajaran Islam. Berdirinya Persyarikatan ini tidak luput dari etos yang kuat untuk mengamalkan doktrin Islam dalam kehidupan bermasyarakat. Lambat laun, Muhammadiyah tumbuh dan berkembang sebagai organisasi terbesar di Indonesia. Bahkan, dalam perkembangannya di era kekinian, ia tumbuh dan memikat warga internasional, khususnya karena keberhasilannya pada sisi amal usaha. Setidaknya ada tiga ranah utama bidang sosial yang manjadi garapan Muhammadiyah; pendirian berbagai sekolah modern (school ing ); pelayanan kesehatan seperti rumah sakit, rumah bersalin, poliklinik, dan semacamnya (healing); dan santunan sosial seperti panti asuhan, panti jompo, dan bantuan karitatif lainya (feeding).

Saat ini, di tengah kehidupan umat yang masih didera masalah kemiskinan dan pendidikan rendah, Muhammadiyah menghadapi tantangan berat. Etos pembaharu di kalangan aktivisnya mulai mengalami keruntuhan. Sehingga, pertanyaan yang perlu dikemukakan adalah apakah selama ini persebaran amal usaha sudah menjadi cermin bagi etos kerja Muhammadiyah dalam kontribusinya membangun peradaban?

Muhammadiyah memiliki banyak lembaga yang sukses mencetak para kader berkualitas. Hal tersebut tak bisa dipungkiri, terlebih organisasi Islam ini telah menjadi wadah bagi terbentuknya tokoh bagi peradaban bangsa yang berkemajuan. Salah satu wadah yang menuai kesuksesan adalah Hajjah Nuriyah Shabran, pondok kader Muhammadiyah, yang lebih akrab disebut Pondok Shabran.

\section{Diaspora Kader Muhammadiyah}

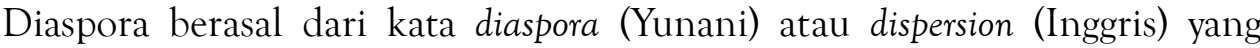
bermakna leksikal pencar atau penyebarluasan. Bentuk verba dari kata diaspora adalah diaspeiro, yaitu menyebar ke luar negeri atau menyebar ke sekitar. Pada saat ini, para ilmuwan sosial menggunakan istilah diaspora untuk merujuk kepada para imigran yang tinggal di daerah perantauan dan melahirkan generasi baru di luar negeri. Mereka semua tetap menjaga hubungan kekeluargaan satu sama yang lain. Mereka juga senantiasa melakukan pulang ke daerah asal secara berkala.

Pada awalnya, istilah diaspora digunakan untuk penyebaran bangsa Yahudi di berbagai negara. Namun dalam perkembangannya, kata ini dipakai untuk menggambarkan diaspora Armenia dan Yunani. Ketiga diaspora ini mempunyai 
identifikasi keagamaan yang sangat kuat dan suatu hubungan kejiwaan dengan daratan asal mereka yaitu Zion, Ararat dan Hellas. Studi yang fokus mengkaji diaspora, baru ada pada akhir abad ke-20, sehubungan dengan terjadinya generalisasi makna terhadap diaspora. ${ }^{1}$

Menurut Steven Vertovec, diaspora adalah proses penyebaran, yaitu masyarakat yang tinggal di daerah asing, serta tempat atau wilayah geografis di mana mereka tinggal atau berdiaspora. Secara sosiologis dan antropologis, masyarakat yang berdiaspora mengalami pola perubahan akibat interaksi dan adaptasi dengan komunitas baru.

Vertovec menjelaskan diaspora dalam tiga bentuk yakni bentuk sosial, jenis kesadaran, dan model produksi budaya. ${ }^{2}$ Konstribusi pendidikan kader Pondok Shabran terhadap diaspora kader Muhammadiyah, dapat dikategorikan sebagai diaspora dalam bentuk sosial. Pondok Shabran memenuhi kriteria dari karakteristik diaspora yang dikemukakan Vertovec. Pertama, diaspora Pondok Shabran terbentuk karena hubungan sosial yang menempel dalam ikatan sejarah dan geografi, sehingga secara umum diaspora $\square$ dilihat sebagai akibat dari perpindahan sukarela (atau terpaksa) kader dari suatu lokasi, yakni seluruh propinsi di Indonesia.

Kedua, kader Pondok Shabran memiliki kesadaran mempertahankan identitas Muhammadiyah. Ketiga, identitas dibentuk oleh pengalaman sejarah ketika menuntut ilmu di Pondok Shabran. Keempat, para alumni program pendidikan kader Pondok Shabran berdiaspora di berbagai daerah, mulai dari struktur ranting hingga pimpinan pusat Muhammadiyah.

\section{Etos Diaspora KH. Ahmad Dahlan}

Etos diaspora gerakan Muhammadiyah dapat dilihat pada pesan KH. Ahmad Dahlan,

"Kelak anak-anak kita akan tersebar bukan saja di seluruh Indonesia, kemungkinan juga di seluruh dunia, dan bukan saja dibenum karena keahliannya saja atau menuntut ilmu pengetahuan, tetapi kemungkinan juga karena dengan hubungan perkawinan." ${ }^{3}$

1 Steven Vertovec, "Religion and Diaspora" dalam Peter Antes, Armin W. Geertz, Randi R. Warne

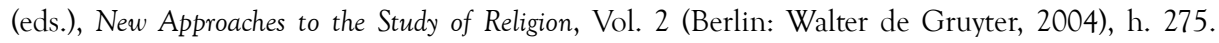

$2 \quad$ Ibid., h 297.

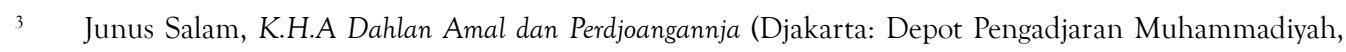
1968), h. 52. 
Pesan ini mengandung visi yang melampaui zaman. KH. Ahmad Dahlan sudah memikirkan mengenai masalah diaspora di tubuh para kader Muhammadiyah. Adapun bentuk diaspora internal gerakan, oleh Dahlan disebutkan melalui pesan yang singkat, tetapi memberikan arti mendalam;

"Muhammadiyah sekarang ini lain dengan Muhammadiyah yang akan datang.

Maka teruslah kamu bersekolah, menuntut ilmu di mana saja. Jadilah guru, kembalilah kepada Muhammadiyah. Jadilah dokter, kembalilah kepada Muhammadiyah. Jadilah master, insinyur dan lain-lain, dan kembalilah kepada Muhammadiyah." ${ }^{4}$

Anjuran yang dilakukan Dahlan mengungkapkan bahwa Muhammadiyah menginginkan para aktivisnya agar memiliki pengetahuan beragam. Melalui jalan ini, para kader diharapkan dapat berkontribusi dan mengisi berbagai agenda kebangsaan dan keumatan yang menjadi arah gerak Muhammadiyah. Tetapi, sebelum melakukan diaspora gerakan, perlu didasari dengan etos kader yang kuat. Sebelum berdiaspora, penguatan etos Muhammadiyah, baik kesadaran individu maupun kolektif, hendaknya dijiwai dengan pemikiran Islam yang berkemajuan. Spirit ini menuntut semua kader untuk melakukan transformasi sosial bagi kepentingan umat dan bangsa.

\section{Kontinuitas dan Diskontinuitas}

\section{Pendidikan Kader Pondok Hajjah Nuriyah Shabran (1982-2014)}

Istilah kontinuitas dan diskontinuitas dalam tulisan ini, dapat dikaitkan dengan konsep kontinuitas dan perubahan (continuity $\square$ and $\square$ change) yang dikemukakan Harry J. Benda. Namun, dalam hal ini, penulis menggunakan perspektif Foucault seperti dikutip Ahmad Nur Fuad dalam Abu-Rabi'. Menurut Nur Fuad, kontinuitas dan diskontinuitas selalu ditandai dengan adanya transformasi (transformation), pergeseran (shift) dan keterputusan epistemik (epistemic rupture) dalam paradigma, pemikiran atau konsep. 5 Dalam perspektif ini, kontinuitas dan diskontinuitas paradigma pendidikan kader pondok Shabran sesungguhnya merupakan hasil interaksi dalam suatu sistem relasi sosial-politik, yang melibatkan berbagai kekuatan sejarah pada kurun waktu tertentu. Bertitik

Ibid., h. 51.

Ahmad Nur Fuad, "Ringkasan disertasi. Kontinuitas dan Diskontinuitas Pemikiran Keagamaan dalam Muhammadiyah (1923-2008): Tinjauan Sejarah Intelektual” (Surabaya: PPS Sunan Ampel, 2010), h. 18. 
tolak dari perspektif tersebut, tulisan ini menggunakan kerangka kontinuitas dan diskontinuitas untuk mengungkap adanya transformasi dan pergeseran paradigma pendidikan Pondok Shabran yang dipengaruhi pemegang kekuasaan Universitas Muhammadiyah Surakarta (UMS).

\section{Gagasan Kontinuitas Djazman Al-Kindi dan Kiai Ahmad Dahlan}

Awal dekade 1980-an, keberadaan Fakultas Agama Islam UMS kurang menggembirakan, baik dari segi kuantitas maupun kualitasnya. Rektor UMS waktu itu, Djazman al-Kindi (yang juga menjadi anggota PP Muhammadiyah) mengajukan konsep pengembangan FAI kepada Pimpinan Pusat Muhammadiyah melalui Rapat Kerja Pimpinan Muhammadiyah (Rakerpim), pada 4-7 Juni 1982. 6

Konsep Pondok Shabran diterima dan dikukuhkan sebagai keputusan resmi dari Rakerpim yang dihadiri oleh jajaran PP Muhammadiyah dan PWM seIndonesia. Dalam butir ke-9 keputusan Rakerpim tertulis: "Pimpinan Pusat agar mengkonkretkan rencana kaderisasi tingkat akademik serta mengumumkan pelaksanaan rencana tersebut." Pelaksana dari keputusan tersebut oleh PP Muhammadiyah diamanahkan kepada UMS.

Begitu pula, upaya serius UMS untuk mengembangkan FAI didukung keluarga Ibu Hajjah Nuriyah Shabran yang telah selesai membangun sebuah unit gedung yang terdiri dari 10 lokal dengan dua lantai, lengkap dengan fasilitas mebel dan perkantoran. Hajjah Nuriyah menghadap UMS untuk menyampaikan keinginannya mewakafkan tanah dan gedung tersebut. Akhirnya, nama pewakaf tersebut diabadikan menjadi nama pondok; Pondok Muhammadiyah: Hajjah Nuriyah Shabran UMS.

Program pendidikan Pondok Shabran dimulai pada tahun akademik 1982/ 1983. Namun, baru pada 24 Rabiul Awwal 1403 H, bertepatan dengan 8 Januari 1983, pondok tersebut diresmikan Menteri Agama, Alamsyah Ratuperwiranegara.

Awalnya, Djazman al-Kindi mengadakan program pendidikan pondok yang ditujukan untuk mengembangkan proses belajar-mengajar di Fakultas Ushuluddin dan Tarbiyah UMS. Di kemudian hari, para lulusan dua fakultas ini dapat memperoleh bekal ilmu yang memadai untuk menjadi guru atau mubaligh.

Saat itu, Djazman menyatakan, Pondok Shabran akan dikembangkan sebagai pusat studi ilmu agama Islam. Tujuan lebih khususnya untuk mengembangkan

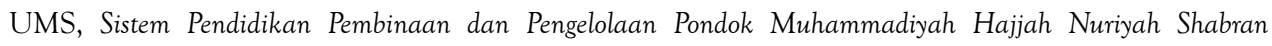
Universitas $\square$ Mhammadiyah $\llbracket$ Surakarta (Naskah tidak diterbitkan). 
pondok sebagai “...pusat pendidikan yang secara bertahap dapat diikhtiarkan untuk menghilangkan dualisme dalam sistem pendidikan di kalangan umat Islam sekaligus menghilangkan kesan dikotomi antara ilmu pengetahuan umum dan ilmu pengetahuan agama yang selama ini sering dipertentangkan secara tajam."7

Dalam pidatonya, Djazman menyebutkan tentang tujuan pendidikan Muhammadiyah ialah "membentuk manusia muslim, berakhlak mulia, cakap, percaya pada diri sendiri, dan berguna bagi masyarakat." Tujuan pendidikan tersebut jelas memenuhi persyaratan individualitas, sosialitas dan moralitas. Tujuan tersebut merupakan formulasi dari ide pembaruan pendidikan $\mathrm{KH}$. Ahmad Dahlan. Pendiri persyarikatan tersebut merumuskan konsep tujuan pendidikan dengan istilah "Kiyai Intelek dan Intelek Kiyai". Kepada beberapa muridnya, Dahlan menegaskan tujuan itu dengan kata-kata "Dadiyo【Kiyai $\operatorname{sing}$

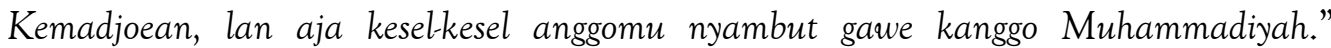
Artinya, jadilah ulama yang berpikir maju, dan jangan berhenti bekerja untuk kepentingan Muhammadiyah. ${ }^{8}$

KH. Ahmad Dahlan mendirikan lembaga pendidikan menengah bernama Qismul Arqa yang bertempat di rumahnya, dengan jumlah murid pertama kali sebanyak 8 orang. Qismul Arqa hanya mengajarkan ilmu agama Islam. Pada 1920, KH. Ahmad Dahlan mendirikan lembaga pendidikan bernama Pondok Muhammadiyah sebagai pengganti dan penyempurnaan sistem pendidikan Qismul Arqa. Pondok Muhammadiyah mengajarkan ilmu agama, pengetahuan umum, melatih fisik, mendidik keterampilan, dan murid-muridnya diasramakan. Dari sini, Dzaman al-Kindi memiliki kontinuitas gagasan pendirian Pondok Muhammadiyah, yang dianggap sebagai produk pembaruan sistem pendidikan KH. Ahmad Dahlan.

Namun, dalam hal ini yang perlu ditegaskan, yaitu ketika Djasman al-Kindi mengatakan, bahwa pondok Muhammadiyah bukanlah pesantren dan berbeda

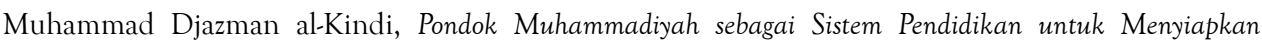
Kader-Kader Muhammadiyah. Pidato Upacara pelepasan dan penerimaan mahasiswa Pondok Hajjah Nuriyah Shabran Universitas Muhammadiyah Surakarta, 8 September 1986, yang dimuat dalam Warta PTM, PP Muhammadiyah Majelis Dikti dan Litbang. Kemudian dipublikasikan dalam buku Tim Pembina Al-Islam dan Kemuhammadiyahan UMM, Muhammadiyah:\Sejarah $\llbracket P e m i k i r a n \llbracket d a n \llbracket A m a l$ Usaha (Malang: Pusat Dokumentasi dan Publikasi UMM, 1990).

8 Djazman al-Kindi, "Pondok Muhammadiyah Sebagai Sistem Pendidikan untuk Menyiapkan KaderKader Muhammadiyah," dalam Tim Pembina Al-Islam dan Kemuhammadiyahan UMM,

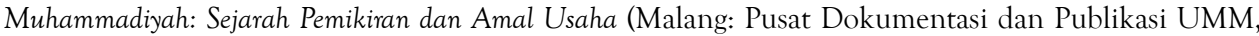
1990), h. 95. 
secara fundamental dengan sistem pendidikan pesantren. Pondok Shabran diselenggarakan berdasarkan sistem pendidikan pondok Muhammadiyah yang didirikan KH. Ahmad Dahlan. Dari semua sistem pendidikan yang pernah diselenggarakan Persyarikatan, Pondok Shabran oleh Djazman diasumsikan sebagai sistem pendidikan yang paling tepat untuk menyiapkan kader-kader organisasi. ${ }^{9}$

Kepada para mahasiswa generasi awal, Djazman berpesan bahwa tatkala hidup di lingkungan Pondok Shabran, hendaknya membiasakan bagaimana menerapkan konsep ilmu amaliah dan amal ilmiah. Dalam praktik yang tidak lain adalah perpaduan antara kecermatan inderawi, akal sehat, dan sikap arif yang dilandasi nilai-nilai Islam, yang seharusnya memotivasi kita untuk bekerja keras, tekun dan sabar, tekun pendirian dan tahan uji, sederhana, dan hidup bersih, sebagai manifestasi pengabdian kepada Allah.

\section{Pergeseran Paradigma Pendidikan Kader Pondok Shabran}

Dalam perjalanannya, paradigma atau sistem Pondok Shabran mengalami dinamika perubahan zaman. Sejak awal, Djazman berpesan supaya terus mengembangkan dan menyempurnakan sistem pondok guna mengikuti laju perkembangan masyarakat, ilmu dan teknologi, serta mengikuti perkembangan Muhammadiyah. Setidak-tidaknya untuk menyesuaikan pondok Muhammadiyah dengan derajat pendidikan di tingkat universitas. Djazman al-Kindi mengharap agar mengevaluasi keluaran Pondok Shabran di masa awal. Sekaligus melakukan penelitian ulang tentang penyelenggaraan pondok yang meliputi manajemen, kurikulum, proses belajar-mengajar, hubungan dosen dan mahasiswa, peran pembina, dan berbagai aspek pendidikan yang lain untuk perbaikan di masa depan. Hasilnya, pondok ini selalu mengalami perubahan sistem karena hubungannya dengan UMS.

\section{Periode Formatif (1982-1992)}

Eksistensi Pondok Shabran tidak muncul secara tiba-tiba. Ia dibangun dari perjalanan panjang pemikiran Djazman. Saat itu, dia menjabat sebagai rektor UMS sekaligus anggota bidang perkaderan PP Muhammadiyah. Sejak Muhammadiyah berdiri, pendidikan dengan model pondok sudah mudah

Djazman al-Kindi, "Pondok Muhammadiyah," h. 97. 
ditemukan keberadaannya. Hanya saja belum dikelola oleh PP Muhammadiyah secara langsung. Menurut M.T. Arifin, Shabran adalah pondok Muhammadiyah pertama yang terintegrasi atau menjadi bagian sistem dengan perguruan tinggi. ${ }^{10}$

UMS menyelenggarakan program pondok untuk menunaikan amanah Rakerpim PP Muhammadiyah. Penyelenggaraannya dimaksudkan untuk mempersiapkan kader-kader Muhammadiyah dengan derajat pendidikan setingkat universitas. Usaha ini sebagai ikhtiar untuk melaksanakan keputusan Muktamar Muhammadiyah ke-37 mengenai penyelenggaraan sekolah kader Muhammadiyah. ${ }^{11}$

Pondok Shabran memiliki tujuan mulia untuk membentuk pemimpin, ulama, dan intelektual. Intinya, pondok ini bervisi mewujudkan kader Muhammadiyah yang terampil di tengah masyarakat sesuai dengan kepribadian Muhammadiyah; berakidah kuat, barakhlak karimah, beramal shalih melalui sikap ilmiah, memiliki potensi diri, profesional, berdedikasi, dan menjadi pelopor dalam mengembangkan Persyarikatan, serta berguna bagi agama, bangsa dan kemajuan dunia." ${ }^{2}$

Shabran merupakan pondok Muhammadiyah mahasiswa pertama yang representatif untuk menggambarkan miniatur kehidupan "Bhinneka Tunggal Ika”. Kebhinnekaan itu, bisa dilihat dalam rekapitulasi mahasiswa pada tiga generasi awal adalah sebagai berikut: ${ }^{13}$

\begin{tabular}{|l|l|c|c|c|c|}
\hline No & Wilayah/ Angkatan & 1982 & 1983 & 1984 & Jumlah \\
\hline 1 & DI Aceh & - & 2 & 2 & 4 \\
\hline 2 & Sumatra Utara & - & 2 & 2 & 4 \\
\hline 3 & Sumatra Barat & $1^{*}$ & 2 & - & 3 \\
\hline 4 & Riau & - & 2 & 1 & 3 \\
5 & Jambi & 1 & 2 & - & 3 \\
\hline
\end{tabular}

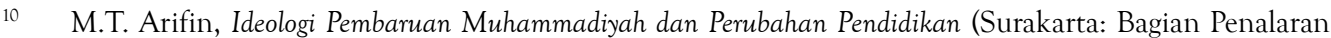
Lembaga Pembinaan mahasiswa UMS, 1985), h. 55.

11 Djazman al-Kindi, "Pondok Muhammadiyah," h. 37.

12 Tujuan pendidikan kader Muhammadiyah Pondok Shabran dirumuskan oleh tim penyusun kurikulum Pondok Shabran UMS yang terdiri dari Tim Pondok PP Muhammadiyah, Pimpinan Wilayah Muhammadiyah Jawa tengah, dan Universitas Muhammadiyah Surakarta yang diputuskan pada 10

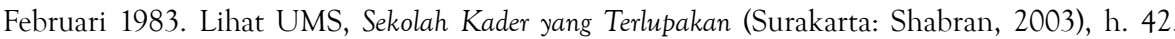

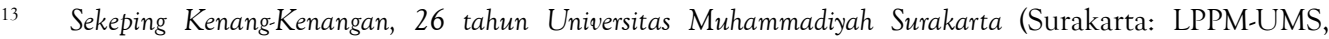
1984), h. 167. 


\begin{tabular}{|l|l|c|c|c|c|}
\hline 6 & Sumatra Selatan & - & 1 & - & 1 \\
\hline 7 & Bengkulu & - & 2 & 2 & 4 \\
\hline 8 & Lampung & - & - & - & 0 \\
\hline 9 & Jawa Barat & 3 & 2 & 4 & 9 \\
\hline 10 & DKI Jakarta & 2 & - & 4 & 6 \\
\hline 11 & Jawa Tengah & $12^{* *}$ & 3 & 4 & 19 \\
\hline 12 & DI Yogyakarta & 5 & 2 & 2 & 9 \\
\hline 13 & Jawa Timur & 5 & 1 & 2 & 8 \\
\hline 14 & Kalimantar Barat & 2 & - & - & 2 \\
\hline 15 & Kalimantan Tengah & - & - & - & 0 \\
\hline 16 & Kalimantan Selatan & - & - & - & 0 \\
\hline 17 & Bali & - & - & - & 0 \\
\hline 18 & Nusa Tenggara Barat & 2 & 1 & 2 & 5 \\
\hline 19 & Nusa Tenggara Timur & 2 & 2 & 4 & 8 \\
\hline 20 & Sulawesi Selatan & 1 & 2 & 1 & 4 \\
\hline 21 & Sulawesi Utara & 1 & 2 & 1 & 4 \\
\hline 22 & Sulawesi Tenggara & 1 & 1 & 1 & 3 \\
\hline 23 & Sulawesi Tengah & - & - & - & 0 \\
\hline 24 & Sulawesi Utara & 2 & 1 & - & 3 \\
\hline 25 & Maluku & - & - & - & 0 \\
\hline 26 & Irian Jaya & 2 & - & 1 & 3 \\
\hline 27 & Timor-Timor & - & - & - & 0 \\
\hline Jumlah Mahasiswa & 42 & 30 & 33 & 15 & 20 \\
\hline Jumlah Wilayah & & & & \\
\hline
\end{tabular}

\section{Keterangan:}

* = pada awalnya 2 orang, seorang tidak lulus (drop』out)

**= pada awalnya 13 orang, seorang tidak lulus (drop』out)

Pondok Shabran dikelola oleh dua institusi. Pada rutinitas-akademis, dikelola oleh bidang akademis di bawah pengawasan rektor UMS. Pada aktivitasnya sehari-hari dipimpin oleh seorang direktur pondok yang didampingi sekretaris 
pondok. Dengan demikian, Pondok ini tidak mempunyai kyai khusus seperti pesantren lainnya. Sementaraldi bidang non-akademik dikelola badan pembina UMS. Perkuliahan pondok, dikelola oleh pimpinan pondok di bawah pengawasan PP Muhammadiyah di Yogyakarta. Sedangkan untuk aspek sosial didampingi para pimpinan Muhammadiyah Sukoharjo. ${ }^{14}$

Pada dasarnya, Pondok Shabran memiliki dua paket perkuliahan yang harus diselesaikan mahasiswa. Pertama, paket fakultas, merupakan kelompok mata kuliah yang ditawarkan oleh Fakultas Ilmu-ilmu Agama Islam (FIAI) UMS sesuai dengan kurikulum yang berlaku di IAIN dan berada di bawah Departemen Agama.『Kedua, paket pondok merupakan kelompok mata kuliah yang ditawarkan pondok Hj. Nuriyah Shabran untuk mencapai tujuan. ${ }^{15}$ Pengasuh Pondok Sobron berasal dari latar belakang yang bermacam-macam dengan keahlian yang beragam.

Sumber dana pendidikan Pondok Shabran seluruhya ditanggung oleh UMS atas nama PP Muhammadiyah. Hal tersebut meliputi biaya perkuliahan, administrasi, kegiatan mahasiswa dan fasilitas fisik. Adapun biaya hidup mahasiswa yang mondok ditanggung PWM dan PDM atau orangtua mahasiswa. ${ }^{16}$ Lembaga Pondok Shabran dipimpin dan dikelola oleh seorang direktur, dengan dibantu seorang sekretaris dan staf pembina (pengasuh), serta staf administrasi dan tata usaha. Semua diangkat dan ditetapkan oleh rektor. Dalam menjalankan tugasnya, direktur pondok langsung berada di bawah rektor. Namun, secara fungsional memiliki hubungan dengan FIAI.

Berikut adalah kader lulusan Pondok Shabran dan FAI UMS pada periode pertama, di antaranya;

\begin{tabular}{|l|l|l|l|l|l|}
\hline No & Angkatan & Masukan & Putus Studi & Lulus & Sisa \\
\hline 1 & $1982 / 1983$ & 40 & 7 & 33 & 0 \\
\hline 2 & $1983 / 1984$ & 30 & 7 & 23 & 0 \\
\hline 3 & $1984 / 1985$ & 33 & 4 & 29 & 0 \\
\hline 4 & $1985 / 1986$ & 37 & 7 & 28 & 2 \\
\hline 5 & $1986 / 1987$ & 44 & 9 & 35 & 0 \\
\hline 6 & $1987 / 1988$ & 42 & 4 & 37 & 1 \\
\hline
\end{tabular}

14 MT. Arifin, Ideologi Pembaruan, h. 43

15 MT Arifin, Ibid., h. 87.

16 Sekolah $\square$ Kader $\square$ yang $\square$ Terlupakan, h. 9. 


\begin{tabular}{|l|l|l|l|l|l|}
\hline 7 & $1988 / 1989$ & 39 & 5 & 31 & 3 \\
\hline 8 & $1989 / 1990$ & 31 & 1 & 27 & 3 \\
\hline 9 & $1990 / 1991$ & 37 & 9 & 28 & 0 \\
\hline 10 & $1991 / 1992$ & 30 & 1 & 27 & 2 \\
\hline 11 & $1992 / 1993$ & 17 & 3 & 11 & 3 \\
\hline & Jumlah & 380 & $\mathbf{5 7}$ & 309 & 14 \\
\hline & Prosentase & $100 \%$ & $\mathbf{1 5 \%}$ & $\mathbf{8 1 , 3 2 \%}$ & $\mathbf{3 , 6 8} \%$ \\
\hline
\end{tabular}

Dari data tersebut terlihat bahwa tingkat keberhasian pondok dalam meluluskan peserta didik. Lulus tepat waktu mencapai $81,32 \%$, sedangkan yang putus studi sebanyak $15 \%$, dan yang lulus tidak tepat waktu 3,68\%. Periode formatif ini, Shabran seakan menjadi pondok kesayangan rektor. Pada periode ini, terbukti eksistensinya yang dirasakan oleh masyarakat, terutama di Persyarikatan. Generasi awal periode tersebut mampu melakukan transformasi di sejumlah posisi strategis di struktur Muhammadiyah.

\section{Periode II (1993-1997)}

Titik balik terjadinya pergeseran paradigma pendidikan Pondok Shabran pada periode pertama adalah terjadinya suksesi rektor dari M. Djazman al-Kindi kepada Malik Fadjar. Banyak yang menilai baahwa sejumlah kebijakan yang dikeluarkan pada masa kepemimpinan Malik Fadjar sangat radikal. Konon, beasiswa kader dianggap sebagai pemborosan atau memanjakan kader. Program pondok dengan model lama, warisan Djazman al-Kindi, ditutup. Kemudian digantikan dengan program baru, yaitu reorientasi pengelolahan pondok yang mengarah pada pemberdayaan universitas. Pondok memiliki fungsi sebagai lembaga pendidikan tinggi dan pusat studi keislaman dengan Pola Ilmiah Pokok "IPTEK Profetik".

Dilihat dari segi sistem pendidikan, antara periode pertama I periode II terdapat perubahan dan perbedaan yang cukup mendasar. Dilihat dari tujuannya, pendidikan Pondok Shabran yaitu:

"Pendidikan Pondok bertujuan menyiapkan 'ulama-intelek' dan atau 'intelekulama', yang memiliki kemampuan sebagai: 1) pembimbing spiritual dan rujukan keagamaan masyarakat; 2) penyampaian pesan-pesan keagamaan yang berkaitan dengan kehidupan umat yang aktual; 3) penerjemahan gagasangagasan inovatif ke dalam bahasa yang komunikatif dan mudah dicerna umat; 
4) perumus pesan-pesan keagamaan (dalam al-Qur'an dan al-Sunnah), berupa pandangan dunia, sistem nilai, atau system norma yang sesuai dengan arah perkembangan zaman.” 17

Secara kelembagaan, kedudukan Pondok Shabran mengalami perubahan. Pada periode I, Shabran berada di bawah pengawasan rektor secara internal. Namun saat ini, pengelolaannya ada pada lembaga studi Islam yang secara struktural berada di bawah otoritas pembantu rektor II. Secara eksternal, Shabran tidak lagi menjadi proyek kerjasama PP Muhammadiyah/Aisyiyah dan PWM/Aisyiyah.

Sumber dana dan pengelolaan pondok juga mengalami perubahan. Dana operasional dikelola secara mandiri. Sehingga mahasiswa yang mondok dipungut biaya asrama dan SPP perkuliahan di UMS. ${ }^{18}$ Khusus untuk utusan PWM/PDM yang memilih jurusan Syari'ah dan Ushuluddin, UMS memberikan beasiswa berupa keringanan pembayaran dana pengembangan dan SPP sebesar 50\%.

Paradigma Pondok Shabran pada periode II mengalami perubahan mendasar terutama pada kegiatan kurikuler. Kegiatan kurikuler pondok diterapkan secara berjenjang: Jenjang awal/program dasar (al-barnamaj】al-I'dady) ditempuh selama tiga semester; Jenjang menengah/program madya (al-Barnamaj】al-Mutawasithy) ditempuh selama tiga semester; dan Jenjang akhir/program paripurna (al-Barnamaj al-takmily) ditempuh selama dua semester. Jadi, total program studi diselesaikan dalam 4 tahun atau 8 semester.

Kurikulum Pondok Shabran berubah total, di mana kurikulum Pondok berdiri sendiri (single entity) dan tertutup (excslusive) dan dikotomik (tidak memiliki kaitan) dengan perkuliahan di UMS. Sehingga, ketika terdapat mata kuliah yang memiliki fungsi sama, antara perkuliahan pondok dan fakultas, tidak ada proses yang padu. Dalam konteks ini, seluruh mahasiswa wajib mengikuti perkuliahan tersebut, meski materi tersebut sudah dipelajari di kelas fakultas. Karena itu, pada posisi ini letak diskontinuitas terjadi.

Dari sisi penamaan dan fungsi mata kuliah terjadi tumpang tindih dan pengulangan antara perkuliahan di pondok dan fakultas, khususnya FAI. Kesan tumpang tindih dan pengulangan ini datasi dengan metode dan pendekatan

Sekolah $\llbracket$ Kader $\square$ Yang $\llbracket$ Terlupakan, h. 32 .

18 SPP pondok ditetapkan sesuai dengan standar biaya kos, sehingga tidak memberatkan mahasiswa karena hampir sama dengan rata-rata harga kamar kos di sekitar Surakarta. Keuntungannya, yang mondok di Shabran akan diberikan pendidikan tambahan. Ibid,】h. 34 . 
yang berbeda di fakultas. Kurikulum pondok sejak 1994 diarahkan pada empat hal: Pendalaman Bahasa Arab, memperbanyak materi metodologi, menggunakan pendekatan text』book, tematik, campuran, dan menyedikitkan beban SKS bagi semester akhir.

Paradigma pondok yang berubah secara fundamental ini dapat dilihat dari data output alumni program pondok di periode II. ${ }^{19}$

\begin{tabular}{|l|l|l|l|l|}
\hline No & Angkatan & Masukan & Putus studi & Lulus \\
\hline 1 & 1993 & 23 & 12 & 11 \\
\hline 2 & 1994 & 48 & 35 & 13 \\
\hline 3 & 1995 & 45 & 34 & 11 \\
\hline 4 & 1996 & 38 & 23 & 15 \\
\hline 5 & 1997 & 37 & 17 & 20 \\
\hline Jumlah & 191 & 121 & 70 \\
\hline \multicolumn{2}{|l|}{ Prosentasi } & $100 \%$ & $63 \%$ & $37 \%$ \\
\hline
\end{tabular}

Data tersebut menunjukkan sebuah paradoks. Dari 191 mahasiswa (100\%), yang putus studi ada sebanyak 121 mahasiswa (63\%) dan yang lulus 70 mahasiswa (37\%). Dalam hal ini, yang patut disalahkan adalah pihak pengelolah pondok, karena paradigma yang salah. Selain konsep yang tumpang tindih, dari sisi pendaftaran masuk dan kelulusan mahasiswa tampak tidak wajar. Lebih tinggi yang putus studi dibandingkan dengan yang lulus. Program pada periode ini, kurang mendapatkan sambutan secara memadai dari alumni, di samping adanya kesulitan untuk proses penempatan alumni.

Pada periode ini dapat diamati dari beberapa faktor persoalan: Pertama, kurangnya koordinasi penyelenggaraan perkaderan baik pada jalur ortom maupun sekolah (menengah dan tinggi). Kedua, ketidakjelasan rekrutmen calon kader dan pemanfaatan kader yang dihasilkan baik melalui jalur ortom maupun sekolah. Ketiga, terjadinya disfungsi lembaga perkaderan, seperti terjadi pada Pondok Shabran sejak 1992, telah dilikuidasi dan berubah fungsi tidak lagi sebagai lembaga pendidikan kader tingkat akademik sebagaimana diamanatkan semula. 


\section{Pondok Shabran Periode III (1999-2007)}

Kontinuitas pada periode III tampak hanya pada rekruitmen calon mahasantri, fasilitas dan pendanaan. Dari sisi paradigma pendidikan, kembali mengalami diskontinuitas dengan periode sebelumnya. Sebab, pada periode ini sistem penyelenggaraan Shabran dirombak secara total. Hal ini berdasarkan masukan dari mahasiswa dan alumni. Perubahan dilakukan dengan cara memisahkan mahasantri yang berasal dari FAI dan non-FAI, dengan menyelenggarakan dua program studi, yaitu Program Studi Agama (PSA - untuk mahasiswa FAI) dan Program Studi Interdisipliner (PSI -untuk mahasiswa Non-FAI UMS).

Program besar UMS berintikan pada keilmuan dan keislaman yang disebut dengan "Ilmiah Profetik", yang dielaborasi lebih nyata dan aplikatif. Maka integasi mahasiswa non-FAI dalam Studi Pemikiran Islam sebagai basis pengembangan Iptek profetik. Sedangkan, pada program PSA (Mahasiswa Pondok Khusus FAI, jurusan tarbiyah, Ushuluddin, dan Syari'ah) diberikan paket kurikulum Tafsir Hadits dan Ilmu Tarjih. Jadi, PSA konsentrasi studinya ialah Tafsir Hadits dan Ilmu Tarjih, dan PSI konsentrasi studinya ialah Pemikiran Islam. ${ }^{20}$

Pada PSI, studi pemikiran Islam mengadopsi kurikulum Jurusan Ushuluddin FAI-UMS. Mahasiswa mendapatkan gelar sarjana agama (S.Ag) dengan Jurusan Ushuluddin, tanpa mengikuti perkuliahan di kampus, kecuali penulisan skripsi dan ujian untuk mata uji negara. Selain itu, juga mendapatkan gelar kesarjanaan fakultas asalnya misalnya, ekonomi, teknik, hukum, psikologi, geografi, FKIP, farmasi dan kesehatan.

Status kemahasiswaan FAI UMS Jurusan Ushuludin diberikan pada program PSI Pondok, dengan konsekuensi membayar biaya herregistrasi setiap semester, tanpa membayar SPP, karena seluruh perkuliahan di pondok. Mahasiswa hanya berkewajiban kepada biaya ujian negara, ujian Skripsi, serta wisuda dan pengambilan ijazah.

\section{Paradigma Kader Integratif dan Transformatif}

Sejak 2003, semangat Pondok Shabran untuk kembali ke khittah sebagai pusat pendidikan kader di tingkat perguruan tinggi semakin bergelora. Untuk itu, diperlukan peran yang aktif, baik dari PP Muhammadiyah/Aisyiyah, PWM, PDM dan para pimpinan di UMS. Hal ini dilakukan untuk memberikan

$20 \quad$ Sekolah $\square$ Kader $\square$ Yang $\square$ Terlupakan, h. 23. 
perhatian kepada pembinaan kader. Dalam bentuk rekruitmen calon mahasantri, kesiapan SDM dalm membantu pendidikan dan pembinaan kader, serta dana untuk menyantuni kader-kader Persyarikatan. Juga diperlukan peran aktif dari pimpinan UMS untuk menyiapkan sumber daya manusia yang mumpuni guna mengelola pondok secara profesional dan berprilaku islami sesuai dengan kepribadian Muhammadiyah.

Sehubungan dengan itu, Temu Nasional I Alumni Pondok Muhamamdiyah HNS-UMS merekomendasikan kepada PP Muhammadiyah untuk: Pertama, perlu revitalisasi penyelenggaraan pendidikan kader, rekruitmen calon kader dan pemanfaatan kader dengan melibatkan sejumlah pihak terkait, yaitu Majelis Tarjih dan Tajdid, Majelis Tabligh, Majelis Pendidikan Tinggi dan Pendidikan Kader PP Muhammadiyah. ${ }^{21}$

Kedua, PP Muhammadiyah dituntut memiliki komitmen untuk menyelenggarakan perkaderan, baik melalui jalur ortom maupun jalur sekolah. Terkait dengan disfungsi pondok Muhammadiyah HNS-UMS, PP Muhammadiyah agar menginstruksikan UMS sebagai penyelenggara program perkaderan tingkat akademik untuk mengaktifkan kembali penyelenggaraan pendidikan kader sesuai dengan amanah awal.

Sejak itu, Pondok Shabran merekonstruki visinya sebagai pusat keunggulan dalam pengembangan kader Muhammadiyah dan pusat pendidikan kader ulama, pemikir dan daiyah yang integratif dan transformatif. Keberadaan pondok tersebut diharapkan menjadi alternatif pendidikan keislaman bagi Persyarikatan pada khsusunya, dan masyarakat luas pada umumnya.

Tujuan Pondok Shabran adalah untuk membina kader Muhammadiyah, sehingga terbentuk kader Persyarikatan yang menguasai ilmu-ilmu keislaman, dengan penghayatan dan pengamalannya sesuai dengan manhaj Muhammadiyah, menguasai teori dan praktik manajemen organisasi, dakwah, serta advokasi masyarakat.

Pondok Shabran menyebut kader ulama, dakwah dan pemikiran Islam adalah sumber daya insani yang menguasai ilmu-ilmu keislaman yang bertumpu pada pengkajian kepada al-Quran dan al-Sunnah, dengan berbagai perangkat keilmuan yang dibutuhkan, serta memiliki komitmen penuh terhadap pelaksanaan syari'ah dan nilai-nilai ajaran Islam. Selanjutnya hasil pemikiran, penghayatan

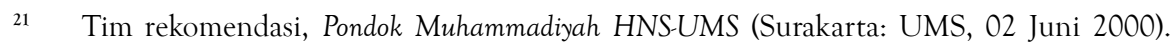


dan pengamalannya akan menjadi benteng izzul Islam】 wa】 al-muslimin, serta menjadi panutan bagi masyarakat luas.

\section{Kembali ke Khittah}

\section{Pondok Shabran Periode IV(2008- sekarang)}

Sejak 2008, Pondok Shabran dikembalikan pengelolaannya seperti pada tahap pertama. Program ini diberi nama "Program Pendidikan Kader Muhammadiyah”. Pada tahap ini, seleksi penerimaan mahasiswa melalui PWMPWM se-Indonesia. Proses pendidikan dan pengajaran juga melibatkan sejumlah pimpinan dari PP Muhammadiyah, misalnya, Rosyad Shaleh, Muclas Abror, Agung Danarto, dan Sukriyanto AR. Hanya saja mulai periode ini, pondok tidak lagi menerima mahasiswa putri. Setiap tahun, Shabran memberikan beasiswa kepada 30 mahasiswa laki-laki utusan dari PWM di seluruh Indonesia.

Mahasiswa Program ini mendapat beasiswa dari UMS. Adapun beasiswa meliputi: (1) biaya asrama (tidak termasuk perlengkapan tidur), (2) biaya pendaftaran UMS, (3) biaya orientasi studi, (4) biaya registrasi setiap semester, (5) dana pembangunan, (6) SPP 8 semester, (7) biaya ujian mid dan semester, (8) Ujian Skripsi dan Wisuda.

Visi, misi dan tujuan masih sama dengan paradigma pendidikan Pondok Shabran Periode III. Dalam rangka mewujudkan semua itu, disusunlah program pendidikan dan pembinaan mahasantri dengan tiga program pokok.

Pelaksanaan program pendidikan terintegrasi dengan FAI UMS sehingga perkuliahan dilaksanakan di pondok dan FAI UMS. Jadi, periode ini konsep seperti era pertama kali pondok dirintis Djazman Al-Kindi. Hanya saja, tidak lagi menerima kader putri. Mahasiswa mendapatkan bimbingan langsung dari PP Muhammadiyah, memperoleh beasiswa penuh, Memperoleh gelar sarjana dari Fakultas Agama Islam UMS. Asrama Pondok yang nyaman, sarana pendidikan memadai, dan akses perpustakaan lengkap.

Sejak tahun 2008 hingga 2014, pondok Shabran perkembangannya dapat dilihat pada tabel berikut: 


\begin{tabular}{|l|l|l|l|l|}
\hline No & Angkatan & Masukan & Putus studi & Lulus \\
\hline 1 & 2008 & 17 & 1 & 16 \\
\hline 2 & 2009 & 29 & 4 & 25 \\
\hline 3 & 2010 & 17 & 2 & 15 \\
\hline 4 & 2011 & 28 & - & proses \\
\hline 5 & 2012 & 25 & - & proses \\
\hline 6 & 2013 & 27 & - & Proses \\
\hline 7 & 2014 & 25 & - & Proses \\
\hline Jumlah & & & & \\
\hline
\end{tabular}

\section{Pondok Shabran dan Diaspora}

Diaspora awal Pondok Shabran dapat merujuk pada hasil penelitian yang dilakukan oleh Diana Ma'ruf (Skripsi UIN Sunan Kalijaga) untuk alumni angkatan 1982-1989 (lulusan tahun 1986-1994). Dari sampel 86 orang, setelah diadakan penyempurnaan dan peninjauan, kiprah Pondok Shabran dapat dikategorikan sebagi berikut, yaitu: birokrasi, intelektual, guru/dosen di Muhammadiyah atau non-Muhammadiyah (Negeri/Swasta), sebanyak 50 orang (58,14\%), ulama/ pimpinan agama sebanyak 9 orang (10,47\%), intelek-ulama sebanyak 22 orang $(25,58 \%)$. dan Wiraswasta sebanyak 5 orang $(5,81 \%)$. Di masa awal Pondok Shabran menunjukkan diaspora ke berbagai bidang kehidupan.

Penulis membagi diaspora menjadi dua, yaitu dispora internal dan dispora eksternal. Diaspora internal adalah persebaran kader alumni Shabran yang berdiaspora di internal Muhammadiyah, sedangkan diaspora eksternal adalah persebaran benih-benih perubahan yang dilakukan kader di luar Persyarikatan. Pemisahan ini sebenarnya hanya pada wilayah kerja, namun keduanya ditujukan untuk transformasi sosial.

\section{Diaspora Internal}

Diaspora Muhammadiyah ke dalam merupakan kewajiban yang tidak dapat ditinggalkan. Sebab, Muhammadiyah merupakan organisasi kader dan bertugas untuk menjadi penerus dan penyempurna organisasi. Kerja-kerja yang dilakukan merupakan penguatan jaringan, upaya memberikan dorongan, serta kritik terhadap Muhammadiyah. 
Pondok Shabran mendelegasikan para kader terbaiknya ke Muhammadiyah, dengan memberikan corak yang berbeda. Ia juga mengantarkan kader terbaik untuk memberikan pencerahan kepada Muhammadiyah. Pengabdian ini sebagai ciri gerakan ilmu sebagaimana yang menjadi tuntunan bagi Islam dan Muhammadiyah.

Dalam diaspora internal, kebanyakan kader Shabran tersebar di wilayah intekeltual-akademisi, amal usaha, dan menjadi pimpinan di Peryarikatan. Di antara mereka, misalnya, Ahmad Norma Permata (Ketua LPCR PP Muhammadiyah), Syamsul Hidayat (Wakil Ketua Majelis Tabligh PP Muhammadiyah dan Kaprodi Shuluddin UMS Surakarta), Imron Rosyadi (Sekretaris Majelis Tarjih dan Tejdid PWM Jawa Tengah dan Kaprodi Syariah UMS), Mahli Zainuddin Tago (Dekan FAI UMY), Sudarman (PWM Kalimantan Timur), Zulkarnain (Politisi), (Pidie PDM Aceh), Ichwan Syamsuddin (PWM NTB), Drs. Ahmad Jaiz, (Ketua PWM Kalimantan Barat), Abdul Wahab (Majelis Tarjih dan Tajdid NTB), Pardjiman Latief (Dekan FAI Universitas Ahmad Dahlan dan Waharjani ketua LPIK UAD), Bunyamin (Pembantu Rektor III Universitas Muhammadiyah Prof. HAMKA), Irawan Sukma (PKU Muhammadiyah Palembang), Sudarno Shobron (Kaprodi Pasca UMS), Muhsana Pasaribu (Rektor UM Sumatra Utara), Masriwati Malik (Dosen UM Makasar), Suprayitno, (Wakil Ketua PWM Samarinda) dan lain-lainnya.

\section{Diaspora Eksternal}

Diaspora keluar merupakan bentuk keniscayaan yang dilakukan oleh Muhammadiyah guna menciptakan masyarakat ideal. Disapora keluar terbagi mejadi dua, yaitu Muhammadiyah secara kolektif dan kader Muhammadiyah secara individu. Bentuk diaspora gerakan dalam bentuk secara individu merupakan sesuai dengan disiplin keilmuan kader dan spesialisasi yang dimiliki oleh masingmasing kader dalam melakukan perubahan sosial

Dalam konteks perluasan benih-benih perubahan di luar Muhammadiyah alumni bergerak juga di wilayah intelektual-akademik, birokrat-politisi dan bisnis. Di antara mereka, misalnya, Khaerani (DPD RI dari Bengkulu), Fakruddin (KemenkumHAM), Rikza Tamrim (Politisi PAN), Ahmad Rusdi (Departemen Agama Pusat), Murtiningsih (IAIN Palembang), Fajar Riza Ul-Haq (Direktur Ma'arif Institute $\llbracket$ for $\llbracket$ Culture $\llbracket$ and $\llbracket$ Humanity), Zuli Atmono (Bupati Karanganyar), Zaky Fadad dan Karoma (dosen IAIN Palembang), Zaim (dosen FKIP UNES 
Semarang), Zakiyuddin Baidhawy (dosen STAIN Salatiga), Sudir Nyengka (Direktur Pesantren Gombara Sulawesi Selatan), Palatua (Kepala Pengadilan Tinggi Agama Sumatra Barat), Sulthan (pengusaha bersama pak Basofi, mantan Gubernur Jawa Timur), Ahmad Alkatiri, (Pejabat Kanwil Depag Kupang NTT), Hasan Basri (dosen IAIN Aceh) dan lain-lain.

Data: Kontinuitas dan Diskontinuitas

\begin{tabular}{|c|c|c|c|c|}
\hline \multirow{2}{*}{$\begin{array}{c}\text { Komponen } \\
\text { Program }\end{array}$} & \multicolumn{4}{|c|}{ Periodesasi } \\
\hline & $1982-1992$ & 1993-1997 & $1998-2007$ & 2008- Kini-Esok \\
\hline $\begin{array}{l}\text { Program } \\
\text { Pendidikan }\end{array}$ & $\begin{array}{l}\text { 1. Sarjana Muda } \\
\text { Khusus FAI } \\
\text { (1982-1984) } \\
\text { 2. Strata 1 Khusus } \\
\text { FAI (1965- } \\
\text { 1992) }\end{array}$ & $\begin{array}{l}\text { Strata } 1 \text { FAI dan } \\
\text { Non-FAI } \\
\text { (Integratif } \\
\text { Konsentrasi Studi) }\end{array}$ & $\begin{array}{l}\text { Strata } 1 \\
\text { FAI dam Non-FAI } \\
\text { (Dekotomis } \\
\text { Konsentrasi } \\
\text { Studi) }\end{array}$ & $\begin{array}{l}\text { Strata } 1 \text { Khusus } \\
\text { FAI }\end{array}$ \\
\hline $\begin{array}{l}\text { Tujuan } \\
\text { Perkaderan }\end{array}$ & $\begin{array}{l}\text { Membentuk kader } \\
\text { ulama dan } \\
\text { pemimpin } \\
\text { Muhammadiyah }\end{array}$ & $\begin{array}{l}\text { Memberikan } \\
\text { wawasan keislaman } \\
\text { dan } \\
\text { Muhammadiyahan } \\
\text { kepada mahasiswa } \\
\text { peminat }\end{array}$ & $\begin{array}{l}\text { Membentuk kader } \\
\text { ulama-intelek atau } \\
\text { intelek-ulama dan } \\
\text { organisatorik } \\
\text { Muhammadiyah }\end{array}$ & $\begin{array}{l}\text { kader } \\
\text { Muhammadiyah } \\
\text { yang mampu } \\
\text { menjadi "Ulul } \\
\text { Albab dan } \\
\text { Rijaluddin" }\end{array}$ \\
\hline $\begin{array}{l}\text { Konsentasi } \\
\text { keilmuan }\end{array}$ & $\begin{array}{l}\text { Ilmu-ilmu } \\
\text { keislaman, } \\
\text { Muhammadiyah } \\
\text { dan manajemen } \\
\text { organisasi }\end{array}$ & $\begin{array}{l}\text { Ilmu-ilmu Islam } \\
\text { tingkat dasar dan } \\
\text { Muhammadiyah }\end{array}$ & $\begin{array}{l}\text { FAI: Tafsir hadits, } \\
\text { Ketarjihan dan } \\
\text { Kemuhammadiya- } \\
\text { han } \\
\text { Non-FAI: } \\
\text { pemikiran Islam } \\
\text { dan } \\
\text { Muhammadiyah }\end{array}$ & $\begin{array}{l}\text { Ilmu-ilmu } \\
\text { keislaman, } \\
\text { Muhammadiyah } \\
\text { dan Ketarjihan }\end{array}$ \\
\hline
\end{tabular}

\section{Penutup}

Sejak berdiri pada1982, Pondok Muhammadiyah Hajjah Nuriyah Shabran UMS telah mengalami kontinuitas dan diskontinuitas paradigma pendidikan dan pengelolaan. Pada periode I, Shabran dikhususkan bagi mahasiswa Fakultas Agama Islam UMS yang merupakan utusan kader Muhammadiyah dari berbagai PWM dan PWA se-Indonesia.

Periode II, berjalan sejak 1993-2007, bekerjasama dengan PP Muhammadiyah "dihentikan". Kemudian, Shabran mulai menerima calon mahasiswa dari berbagai fakultas di UMS. Dalam perjalanannya pilihan ini membawa sejumlah kesulitan 
tersendiri dalam implementasinya. Berdasarkan pengalaman itu, maka periode III dilakukan pemilahan kelas antara FAI dan non-FAI, yang selanjutnya disebut Program PSI (bagi mahasiswa non-FAI) dan Program PSA (bagi mahasiswa FAI).

Kemudian periode IV, mulai tahun 2008, Pondok Shabran dikembalikan paradigmanya seperti pada periode I. Program ini diberi nama Program Pendidikan Kader Muhammadiyah. Pada periode ini, seleksi penerimaan mahasiswanya dilakukan melalui PWM-PWM se-Indonesia. Namun hanya dikhususkan pada mahasiswa putra. Mahasiswa Program ini mendapat beasiswa dari Universitas Muhammadiyah Surakarta.[]

\section{Bibliografi}

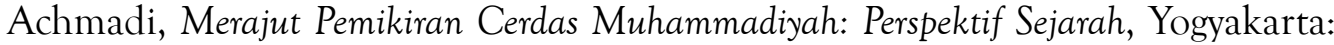
Suara Muhammadiyah, 2010.

al-Kindi, Muhammad Djazman, "Pondok Muhammadiyah Sebagai Sistem Pendidikan untuk Menyiapkan Kader-Kader Muhammadiyah,” dalam Tim Pembina Al-Islam dan Kemuhammadiyahan UMM, Muhammadiyah:

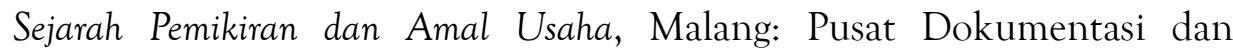
Publikasi UMM, 1990.

al-Kindi, Muhammad Djazman, Pondok $\llbracket$ Muhammadiyah $\llbracket$ Sebagai $\square$ Sistem $\llbracket$ Pendidikan untuk $\square$ Menyiapkan $\square$ Kader-Kader $\square$ Muhammadiyah, Pidato Upacara pelepasan dan penerimaan mahasiswa Pondok Hajjah Nuriyah Shabran Universitas Muhammadiyah Surakarta, 8 September 1986, yang dimuat dalam Warta PTM, September 1986, PP Muhammadiyah Majelis Dikti dan Litbang.

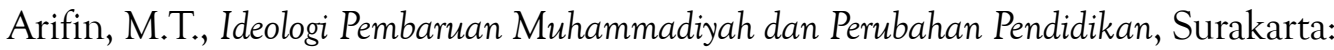
Bagian Penalaran Lembaga Pembinaan Mahasiswa UMS, 1985.

Dahlan, Ahmad, "Kesatuan Hidup Manusia," Abdul Munir Mulkhan, Warisan

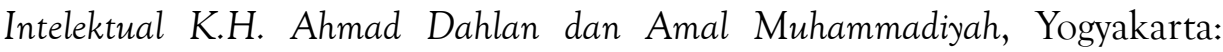
Percetakan Persatuan Yogyakarta: 1990.

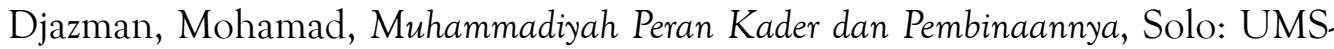
Press, 1989.

Fu'ad, Ahmad Nur, Ringkasan $\square$ disertasi. $\square$ Kontinuitas $\square$ dan $\square$ Diskontinuitas $\square$ Pemikiran

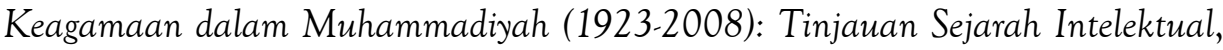
Surabaya: PPS Sunan Ampel, 2010.

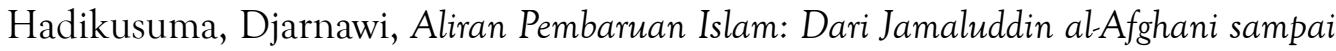
KHA\AhmadロDahlan, Yogyakarta: Persatuan. 


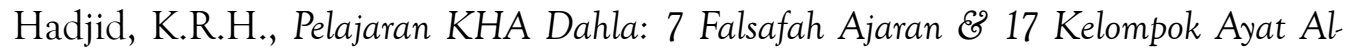
Qur’an,\Yogyakarta: Universitas Muhammadiyah Malang Press, 2005.

Handayani, Nani Sri dan Zahrotul 'Uyun, "Pengaruh Tingkat Religiusitas

Terhadap Kesiapan Menghadapi Perkawinan Mahasantri Pondok Muhammadiyah Hajjah Nuriyah Shabran Surakarta," Tajdida, Vol. 2, No. 2 (Desember 2004).

http://pondokshabran.ums.ac.id/index.php?option $=$ com_content\&view= article\&id=19\&Itemid=27\&limitstart=1 (Diakses pada Juli 2014).

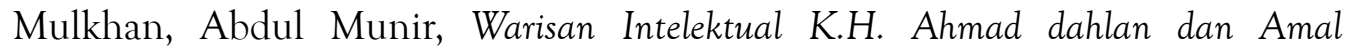
Muhammadiyah, Yogyakarta: Percetakan Persatuan Yogyakarta, 1990.

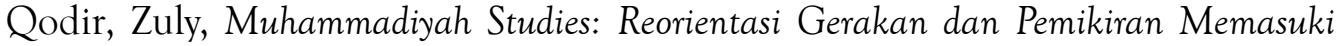
Abad Kedua, Kanisius: 2010, Yogyakarta.

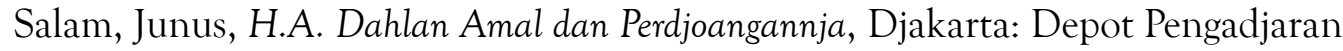
Muhammadiyah, 1968.

Steven Vertovec, "Religion and Diaspora" dalam Peter Antes, Armin W. Geertz,

Randi R. Warne (eds.), New $\llbracket$ Approaches $\square$ to $\square$ the $\llbracket$ Study $\square$ of Religion, Vol. 2 (Berlin: Walter de Gruyter, 2004), hal. 275.

Tim Pembina Al-Islam dan Kemuhammadiyahan UMM, Muhammadiyah:DSejarah

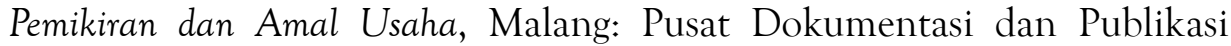
UMM, 1990.

Tim Pondok, Sekeping Kenang-Kenangan, $\square 26 \square$ tahun Universitas $\square$ Muhammadiyah Surakarta, Surakarta: LPPM-UMS, 1984.

Tim Pondok, Sekolah】kader】yang】Terlupakan, Surakarta: PM HNS-UMS, 2003.

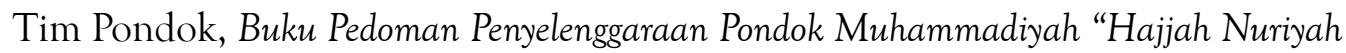

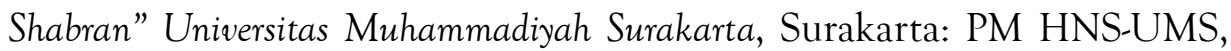
2004.

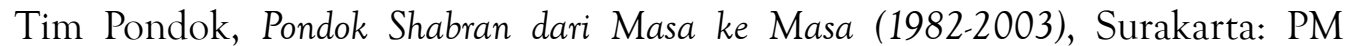
HNS-UMS, 2003.

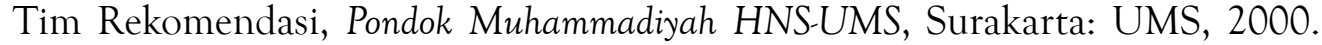
Tuhuleley, Said (ed.), Reformasi Pendidikan₫Muhammadiyah, Yogyakarta: Pustaka SM, 2003. 